\title{
Pattern and predictors of paradoxical response in patients with peripheral lymph node tuberculosis
}

\author{
Supreet BATRA ${ }^{1}$ \\ Govind Singh RAJAWAT ${ }^{2}$ \\ Rajendra Prasad TAKHAR ${ }^{3}$ \\ Manohar Lal GUPTA ${ }^{2}$
}

${ }^{1}$ Department of Respiratory Medicine, V P Chest Institute, Delhi, India

${ }^{1}$ V P Gögüs Enstitüsü, Solunum Bölümü, Delhi, Hindistan

2 Department of Respiratory Medicine, Institute of Respiratory Medicine, S.M.S. Medical College, Jaipur, India

2 S.M.S. Tıp Okulu, Solunum Enstitüsü, Solunum Bölümü, Jaipur, Hindistan

${ }^{3}$ Department of Respiratory Medicine, Goverment Medical College,

Kota, India

${ }^{3}$ Devlet Tıp Okulu, Solunum Bölümü, Kota, Hindistan

\section{SUMMARY}

Pattern and predictors of paradoxical response in patients with peripheral lymph node tuberculosis

Introduction: Many of the patients with lymph node tuberculosis show 'Paradoxical Response" in the form of appearance of new lymph node (LN) or increase in the size of existing $L N$, development of new disease in other organ and worsening of the disease while on treatment. Reason behind such response in only selective patients is not clearly understood. We evaluated the pattern and predictors for paradoxical response $(S)(P R)$ in patients with peripheral lymph node tuberculosis (TB).

Materials and Methods: Study included patients aged > 6 years with peripheral lymphadenopathy of tubercular etiology attending a tertiary care hospital from Jan 2010 to Dec 2010. PR in our study was defined as worsening of pre-existing disease or development of new lesions in a patient who has been on anti-TB therapy for at least 2 weeks.

Results: One hundred ten patients with peripheral lymph node TB were included. Their mean age was $27.5 \pm 5$ years and 68 (62\%) were females. PR occurred in 28 (25\%) patients, at a mean onset time of 6 weeks (range 2-12 weeks) after starting anti-TB medication. Four of these 28 patients experienced PR on two occasions. Of these, 22 (79\%) patients presented with enlarged lymph nodes only, $8(29 \%)$ with new nodes at same or different site and $2(7 \%)$ with discharging sinus. PR was observed more in younger age group $(p>0.05)$, female gender ( $p>0.05)$, unilateral lymphadenopathy $(p>0.05)$ and those with positive AFB on initial examination $(p<0.01)$.

Conclusion: Paradoxical response in peripheral lymph node TB is associated with younger age, female gender, unilateral lymphadenopathy and those with positive AFB on initial examination.

Key words: Tuberculosis, lymphadenitis, paradoxical response (PR)

\section{Yazışma Adresi (Address for Correspondence)}

Dr. Rajendra Prasad TAKHAR

Department of Respiratory Medicine, Government Medical College, KOTA - INDIA

e-mail: fdrrajtakhar@gmail.com 


\section{ÖZET}

\section{Periferik lenf nodu tüberkülozu hastalarında paradoksik yanıtın özellikleri ve göstergeleri}

Giriş: Lenf nodu (LN) tüberkülozu olan hastaların çoğu yeni LN görünümü veya var olan LN'nin boyutunda artış, başka bir organda yeni hastalık gelişimi veya tedavi altında hastalığın kötüleşmesi gibi formlarda paradoksik yanıt (PY) gösterir. Böyle bir yanıtın sadece seçilmiş hastalarda olmasının arkasındaki sebepler halen anlaşılamamaktadır. Periferik LN tüberkülozu olan hastalarda PY'nin özellikleri ve göstergeleri incelendi.

Materyal ve Metod: Araştırmaya Ocak 2010-Aralık 2010 tarihleri arasında etyolojisi tüberküloz olan periferik lenfadenopatisi nedeniyle üçüncü basamak hastaneye başvuran, $\geq 6$ yaş hastalar dahil edildi. Var olan hastalığın kötüleşmesi veya en az iki haftadır antitüberküloz tedavi alan hastada yeni lezyonların gelişmesi PY olarak tanımlandı.

Bulgular: Periferik LN tüberkülozu olan 110 hasta dahil edildi. Ortalama yaşları $27.5 \pm 5$ bulundu ve 68 (\%62)'i kadındı. PY 28 (\%25) hastada görüldü, antitüberküloz tedavi başladıktan sonra ortalama oluşum süresi 6 hafta (2-12 hafta arasında) bulundu. Yirmi sekiz hastadan dördünde iki kez PY görüldü. Hastaların 22 (\% 79)'sinde sadece genişlemiş $L N^{\prime} l e r, 8$ (\%29)'inde aynı veya farklı bölgelerde yeni LN'ler, 2 (\%7)'sinde ise boşalan sinüs görüldü. PY daha genç yaş grubunda ( $p>0.05)$, kadın cinsiyette $(p>0.05)$, tek taraflı lenfadenopatide $(p>0.05)$ ve ilk muayenede pozitif AFB olanlarda $(p<0.01)$ daha fazla görüldü.

Sonuç: Periferik LN tüberkülozunda PY genç yaş, kadın cinsiyet, tek taraflı lenfadenopati ve başlangıçta testlerde pozitif AFB olmasıyla ilişkilidir.

Anahtar kelimeler: Tüberküloz, lenfadenit, paradoksik yanıt

\section{INTRODUCTION}

Peripheral lymph node tuberculosis is observed in about $5 \%$ of all new TB patients and constitutes about $30-55 \%$ of total extra-pulmonary TB cases (1). In spite of effective treatment, many of the patients with lymph node tuberculosis show appearance of new lymph node or new disease in other organ, abscess/ sinus formation and/or increase in the size of existing lesion(s) while on treatment. This phenomenon, known as 'Paradoxical Response (PR) is particularly more common in CNS than lymph node TB and HIV infected than non HIV infected patients (2-7). The PR in lymph node TB during anti-tuberculosis therapy has been well documented in $20-30 \%$ of all patients receiving anti-TB therapy and is considered to reflect an immune response that occurred during killing of the micro-organisms $(4,8,9)$.

Why such response occurs in only some of the patients and not in others and the factor(s) responsible for it are not clearly understood. Therefore, the present study was designed to study the pattern and predictor(s) of paradoxical response in patients with TB lymphadenitis.

\section{MATERIALS and METHODS}

The present study included patients with peripheral lymphadenopathy, who attended the outpatient department of Hospital for Chest Diseases and Tuberculosis, during Jan 2010-Dec 2010.
After a detailed history, general physical and local examination, routine tests eg. complete blood count, erythrocyte sedimentation rate (ESR), mantoux test, HIV serology, chest radiography, ultrasound abdomen and sputum examination for acid-fast bacilli, fine needle aspiration cytology (FNAC) of involved node(s) was performed in all patients. A second FNA aspirate was also performed in those having insufficient material/non conclusive cytopathology results. Biopsy of the lymph nodes was performed on the two occasions when repeat FNAC was either negative or doubtful.

Patients found to have cyto-pathological or histopathological evidence of caseating /necrotizing granulomas and/or bacteriological evidence of tubercle bacilli were considered to have tuberculous lymphadenopathy. All such confirmed cases were given rifampicin, isoniazid, ethambutol and pyrazinamide thrice weekly for 2 months followed by rifampicin and isoniazid for 4 months in standard doses. All patients were requested to report every two months for follow up to record PR, if any. Compliance with anti-TB therapy was also monitored at each patient visit. Patients were also instructed to report earlier in case of increase in size of the lymph node or appearance of new lesion or symptoms.

In situation of new node/increase in size of existing node/sinus/abscesses formation PR was differentiated from treatment failure on the following basis:-Stable to increasing weight, resolution of some of the lymph 
nodes or response in the disease of other organ system if any were considered in favour of paradoxical response.

Repeat FNAC/mycobacterial culture (whenever adequate aspirate) was sent in all patients with PR along with simultaneous recording of weight, ESR and any associated systemic symptom, if any.

\section{Analysis of Data}

The data collected were analyzed by using Microsoft Excel, Microsoft Access and Graph Pad In Stat computer software. Pearson's x2 test or Fisher's exact test was used to evaluate correlations between categorical variables, as appropriate. Relationships among continous variables was evaluated using Student's t test. All tests of significance were twotailed, and $\mathrm{p}<0.05$ was considered to reflect significance.

\section{RESULTS}

During the year study period, 110 patients were diagnosed with lymph node tuberculosis. The age of these patients ranged from 6 years to 60 years with a mean age of $27.5+5$ years. The most common age group affected by the disease was 25-34 years (36 patients) followed by $15-24$ years (34 patients). There were 42 males and 68 females (M:F ratio 1:1.6). The time interval between onset of symptoms and time of presentation varied from 15 days to less than 3 months. Other baseline clinical characteristic of patients with peripheral lymph node TB are listed in Table 1.

Twenty-eight patients (\%25) experienced some or other form of PR. Four of these 28 patients experienced two separate PRs; therefore, there were a total of 32 episodes of PR, at a mean onset time of 6 weeks (range 2-12 weeks) after starting anti-TB medication. Of these patients, $22(\% 79)$ presented with enlarged lymph nodes only, $8(\% 29)$ with new nodes at same or different site and $2(\% 7)$ with discharging sinus. Mean age of those with PR was higher as compared to those without PR but among the different age group it was more in age of 15-34 years Characteristics of the PRs and the patients who experienced the PRs are listed in Table 2. When correlations between PR and clinical variables were evaluated $P R$ was more in younger age group $(p>0.05)$, female gender $(p>$ 0.05 ), unilateral lymphadenopathy ( $>>0.05$ ) and those with positive AFB on initial diagnosis $(p<0.01)$. We also observed that those patients who had PR had incomplete resolution (residual nodes)as compared to those without PR at the end of treatment $(p<0.001)$ (Table 3). Surgery other than excision biopsy was not needed in any patient. Multiple aspirations using a wide bore needle were needed only in patients with abscesses.

\section{DISCUSSION}

PR during anti-tuberculosis treatment is a well-known phenomenon first described in 1955 by Chloremis (10). Immunorestitution is believed to be a possible mechanism leading to paradoxical reaction (11). PR has been attributed to host immunologic reactions, with possible mechanisms including a delayed hypersensitivity response, a decrease in immune suppression, or a response to mycobacterial antigens such as tuberculoprotein or other cell products $(4,12)$.

We observed PR in \%25 of our non-HIV infected patients with lymph node TB which is consistent with previous data (8). Risk factors for PR during TB treatment have been explored mainly in HIV-infected patients on highly active antiretroviral therapy $(4,9)$ However limited data are available on PR risk factors in non-HIV-infected patients with lymph node TB. To the best of our knowledge, only two studies have systematically evaluated risk factors in such population $(8,13)$. The only clinical characteristic reported in these study to differ significantly between patients with lymph node TB who did and did not experience PR was median peripheral blood monocyte count at baseline (8). However, although this variable was associated with $P R$ in univariate analysis. Young age, male gender and the presence of local tenderness were independently predictive of $P R$ in lymph node TB patients (13).

In contrast, we found that only initial positive AFB smear in node aspirate to be predictive of $P R$ in lymph node TB patients.

Lymph node TB is more common in women than men (14-17). We found that PR was more often associated with female gender, though not significant, a finding consistent with Polesky et al. (9). We also found that most of the PR occurred in younger age group of 15-34 years. The possible explanation for this could be younger age was predictive for PR because immunologic status has been found to decrease with aging (18). An interesting finding in our study was that all paradoxical responses occurred in the patients with unilateral lymphadenopathy only. However 
Table 1. Baseline clinical characteristic of patients with peripheral lymph node tuberculosis

\begin{tabular}{|c|c|c|}
\hline Variable & Patients $(n=110)$ & \\
\hline Age, mean years $\pm S D$ & $27.5 \pm 5.2$ & \\
\hline Sex, $\mathrm{n}(\%)$ & Male gender, 42 (38) & Female gender, 68 (62) \\
\hline Age, mean years $\pm S D$ & $27.8 \pm 5.3$ & $27.3 \pm 5.2$ \\
\hline Prior active TB therapy, $\mathrm{n}(\%)$ & $8(19)$ & $16(23)$ \\
\hline Comorbidity, n (\%) & 0 & $4(6)$ \\
\hline \multicolumn{3}{|l|}{ Constitutional symptoms } \\
\hline Fever, n (\%) & $22(52)$ & $26(38)$ \\
\hline Weight loss, n (\%) & $12(29)$ & $18(27)$ \\
\hline Appetite loss, n (\%) & $14(33)$ & $20(29)$ \\
\hline Fatigue, n (\%) & $14(33)$ & $26(38)$ \\
\hline Cough, n (\%) & $2(5)$ & 0 \\
\hline \multicolumn{3}{|l|}{ Location of affected lymph nodes } \\
\hline Cervical, n (\%) & $32(76)$ & $56(82)$ \\
\hline Submandibular, n (\%) & $2(5)$ & $6(9)$ \\
\hline Axillary, n (\%) & 0 & $2(3)$ \\
\hline Multiple adenopathy, n (\%) & $8(19)$ & $4(6)$ \\
\hline Unilateral adenopathy & $34(81)$ & $66(97)$ \\
\hline Bilateral adenopathy & $8(19)$ & $2(3)$ \\
\hline Local tenderness & $18(43)$ & $24(35)$ \\
\hline \multicolumn{3}{|l|}{ Baseline Mantoux test } \\
\hline$\leq 20 \mathrm{~mm}$ & $18(43)$ & $42(62)$ \\
\hline$>20 \mathrm{~mm}$ & $24(57)$ & $26(38)$ \\
\hline Combined pulmonary tuberculosis & $4(10)$ & $2(3)$ \\
\hline \multicolumn{3}{|l|}{ Diagnostic procedure } \\
\hline FNAC & $28(67)$ & $48(71)$ \\
\hline AFB-positive & $8(19)$ & $6(9)$ \\
\hline Both & $2(5)$ & $4(6)$ \\
\hline Excision & $4(10)$ & $10(15)$ \\
\hline
\end{tabular}

cause for this is not known and can be purely incidental. In our study it was also interesting to note the trend toward an association between the presence of acid-fast bacilli on the initial diagnostic aspirate smear on examination and subsequent development of paradoxical reactions. This association had been observed only in one study by Hawkey et al. and the reason for this association could be higher bacillary load predisposes patients to develop a paradoxical reactions (PR) (8). Six patients who had a paradoxical reaction $(\mathrm{PR})$ in our study were found to have persistently positive acid fast bacilli (AFB) of aspirate, though all of them had negative culture. Therefore we support the hypothesis of Hawkey et al. that this phenomenon is caused by hypersensitivity to persistent antigen (8). These reactions can occur even after prolonged therapy suggests that the antigenic stimulus may be poorly cleared from disease sites.

Most patients in our study who had paradoxical reponses (PR) recovered without developing any sequelae. In addition, the simpler intervention of aspiration of pus was associated with fewer unwanted side effects. The use of aspiration has been reported to be a successful therapeutic intervention for suppurative post-BCG adenitis, and a report has suggested that aspiration was useful for the treatment of a PR in a patient with lymph node tuberculosis $(19,20)$.

Our study has few limitations. First, Mycobacterium tuberculosis culture was not sent at initial presentation in all the cases. The reason was that most of our patients presented early and had discrete firm nodes. 
Such aspirates were scanty in amount therefore could not be submitted for mycobacterial culture. Second, it was difficult to obtain reliable measurements of lymph node sizes, although lymph mode size was measured with inch tape. Third, it is difficult to differentiate between failure and post-therapy

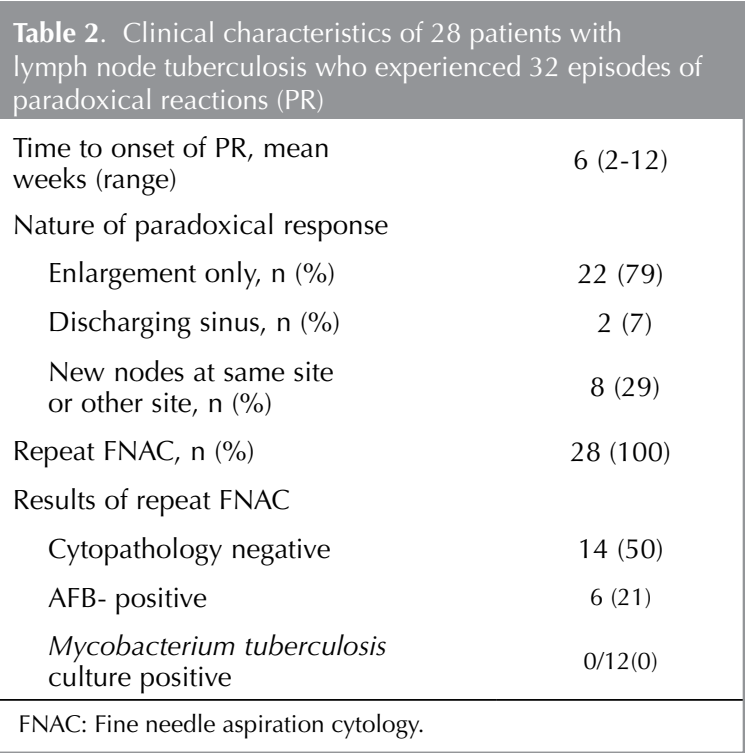

Table 3. Characteristics/findings in relation to the occurrence of paradoxical reactions (PRs)

\begin{tabular}{|c|c|c|c|}
\hline Characteristic & $\begin{array}{c}\text { Patients } \\
\text { with PR } \\
(n=28)\end{array}$ & $\begin{array}{c}\text { Patients } \\
\text { without } \\
\text { PR }(n=82)\end{array}$ & $p$ value \\
\hline Age, mean years \pm S.D & $31 \pm 5.5$ & $26.3 \pm 5.1$ & $>0.05$ \\
\hline \multicolumn{4}{|l|}{ Sex } \\
\hline Male & $8(29)$ & $34(42)$ & $>0.05$ \\
\hline Female & $20(71)$ & $48(58)$ & $>0.05$ \\
\hline Unilateral adenopathy & $28(100)$ & $72(88)$ & $>0.05$ \\
\hline Bilateral adenopathy & 0 & $10(12)$ & $>0.05$ \\
\hline \multicolumn{4}{|l|}{ Baseline mantoux tesr } \\
\hline$\leq 20 \mathrm{~mm}$ & $12(43)$ & $48(59)$ & $>0.05$ \\
\hline$>20 \mathrm{~mm}$ & $16(57)$ & $34(41)$ & $>0.05$ \\
\hline \multicolumn{4}{|l|}{ Diagnostic procedure } \\
\hline FNAC & $24(86)$ & $72(88)$ & $>0.05$ \\
\hline Excision & $4(14)$ & $10(12)$ & $>0.05$ \\
\hline AFB-positive & $10(36)$ & $10(12)$ & $<0.01$ \\
\hline \multicolumn{4}{|l|}{ Outcome } \\
\hline Complete response & 18 & 76 & $>0.5$ \\
\hline $\begin{array}{l}\text { Incomplete response } \\
\text { (residual nodes) }\end{array}$ & 10 & 6 & $<0.001$ \\
\hline
\end{tabular}

paradoxical expansion. Some authors have suggested that lymph node enlargement after therapy in the absence of positive culture may be immunologically mediated and that retreatment is not warranted. However further work is needed to explore how often enlarged lymph nodes after therapy, in the absence of positive culture, resolve spontaneously without further therapy.

To conclude PR is relatively common, occurring in one- quarter of patients with peripheral lymph node $\mathrm{TB}$ and is associated with younger age, female gender, unilateral lymphadenopathy and presence of positive acid-fast bacilli on the initial diagnostic smear. Therefore providing advance warning of the possibility that a paradoxical response(s) might occur, is likely to improve patient's satisfaction and, perhaps, enhance adherence to a prolonged course of anti-TB therapy.

\section{REFERENCES}

1. Asghar RJ, Pratt RH, Kammerer IS, Navin TR. Tuberculosis in south Asians living in the united states, 1993-2004. Arch Intern Med 2008;168:936-42.

2. Chen YM, Lee PY, Su WJ, Perng RP. Lymph node tuberculosis: 7-year experience in Veterans General Hospital, Taipei, Taiwan. Tuber Lung Dis 1992;73:368-71.

3. Byrd RB, Bopp RK, Gracey DR, Puritz EM, The role of surgery in tuberculosis lymphadenitis in adults. Am Rev Respir Dis 1971;103:816-20.

4. Campbell IA, Dyson AJ. Lymphnode tuberculosis: a comparison of various methods of treatment. Tubercle 1977;58:171-9.

5. British Thoracic society research committee. Short course chemotherapy for tuberculosis of lymphnodes: a controlled trial. BMJ 1985;290:1106-8.

6. Labhard N, Nicod L, Zellweger JP. Cerebral tuberculosis in the immunocompetent host: 8 cases observed in Switzerland. Tuber Lung Dis 1994;75:454-9.

7. Narita M, Ashkin D, Hollender ES, Pitchenik AE. Paradoxical worsening of tuberculosis following antiretroviral therapy in patients with AIDS. Am J Respir Crit Care Med 1998;158:157-61.

8. Hawkey CR, Yap T, Pereira J, Moore DA, Davidson RN, Pasvol G, et al. Characterization and management of paradoxical upgrading reactions in HIV-uninfected patients with lymph node tuberculosis. Clin Infect Dis 2005; 40:1368-71.

9. Polesky A, Grove W, Bhatia G. Peripheral tuberculous lymphadenitis; epidemiology, diagnosis, treatment, and outcome. Medicine (Baltimore) 2005;84:350-62. 
10. Choremis CB, Padiatellis C, Zou Mbou Lakis D, Yannakos $D$. Transitory exacerbation of fever and roentgenographic findings during treatment of tuberculosis in children. Am Rev Tuberc 1955;72:527-36.

11. Cheng VC, Yam WC, Woo PC, Lau SK, Hung IF, Wong SP, et al. Risk factors for development of paradoxical response during antituberculosis therapy in HIVnegative patients. Eur J Clin Microbiol Infect Dis 2003;22:597-602.

12. Cheng VC, Ho PL, Lee RA, Chan KS, Chan KK, Woo PC, et al. Clinical spectrum of paradoxical deterioration during antituberculosis therapy in non HIV-infected patients. Eur J Clin Microbiol Infect Dis 2002;21:803-9.

13. Cho $O H$, Park $K H$, Kim $T$, Song $E H$, Jang $E Y$, Lee EJ, et al. Paradoxical responses in non-HIV-infected patients with peripheral lymph node tuberculosis. J Infect 2009;56:5661.

14. Dandapat MC, Mishra BM, Dash SP, Kar PK. Peripheral lymph node tuberculosis: a review of 80 cases. Br J Surg 1990:77:911-2.

15. Subrahmanyam M. Role of surgery and chemotherapy for peripheral lymph node tuberculosis. $\mathrm{Br}$ / Surg 1993;80:1547-8.
16. Ilgazli A, Boyaci H, Basyigit I, Yildiz F. Extrapulmonary tuberculosis: clinical and epidemiologic spectrum of 636 cases. Arch Med Res2004;35:435-41.

17. Aggarwal P, Wali JP, Singh S, Handa R, Wig N, Biswas A. A clinico-bacteriological study of peripheral tuberculous lymphadenitis. J Assoc Physicians India 2001;49:808-12.

18. Wang CS, Chen HC, Yang Cl, Wang WY, Chong IW, Hwang JJ, et al. The impact of age on the on the demographic, clinical, radiographic characteristic and treatment outcome of pulmonary tuberculosis patients in Taiwan. Infection 2008;36:335-40.

19. Banani SA, Alborzi A. Needle aspiration for suppurative post-BCG adenitis. Arch Dis Child 1994;71:446-7.

20. Meybeck A, Just N, Nyunga M, Bourahla M, Wallaert B. Needle aspiration in paradoxical hypertrophy of tuberculous lymphadenitis [in French]. Rev Mal Respir 2003;20:973-7. 